\title{
Religious Tolerance in Multicultural Communities: Towards a Comprehensive Approach in Handling Social Conflict
}

\author{
Ahmad Suradi* \\ Islamic Education Department, \\ Tarbiyah and Tadris Faculty of IAIN Bengkulu-Indonesia \\ John Kenedi ${ }^{* *}$ \\ Islamic Law Department, Law Faculty of IAIN Bengkulu-Indonesia \\ Buyung Surahman ${ }^{* * *}$ \\ Education Curriculum Department, \\ Tarbiyah and Tadris Faculty of IAIN Bengkulu-Indonesia
}

Article Received: 12 ${ }^{\text {th }}$ March 2019; Accepted: 28 ${ }^{\text {th }}$ July 2020; Published: 30st July 2020

\begin{abstract}
This article is aimed to analyze the need for handling social conflict through the planting of tolerance values in multicultural societies that in line with statutory provisions. It is a socioreligious study that, to some extent, applies a legal approach. A library study was conducted by collecting data and information from textbooks, scientific journals, website contents. The legal analysis was based on principles and norms contained in legislation and regulations. It applies Miles and Huberman's interactive analysis model which includes data reduction, data presentation, and conclusion. The study suggested that planting tolerance values is a grand and noble concept that would become an organic part of Indonesia. Tolerance is functioned as a guardian, safeguard, peace-maker, and unifier communication and interaction to realize good relations between community members. Besides, the law on handling of social conflict has covered the mechanism to address this matter by means of conflict prevention, cessation of conflicts, and post-conflict recovery.
\end{abstract}

Keywords: Social Conflict; Religious Tolerance; Multicultural Society; Legal Approach.

How to cite (Chicago 16 th): Suradi, Ahmad, John Kenedi, Buyung Surahman. "Tolerance in Multicultural Communities: Towards a Comprehensive Approach in Handling Social Conflict." Udayana Journal of Law and Culture 4, no. 2 (2020): 229-245. https://doi.org/10.24843/UJLC.2020.v04.i02.p06

doi: https://doi.org/10.24843/UJLC.2020.v04.i02.p06

\footnotetext{
Email/Corresponding Author: suradi@iainbengkulu.ac.id

** Email: johnkenedi@iainbengkulu.ac.id

${ }^{* * *}$ Email: buyungsurahman@iainbengkulu.ac.id
} 


\section{Introduction}

In the reality of social life, conflict often negatively connoted. Apart from these emerging assumptions only as hypotheses in analyzing social phenomena, but still the existence of conflict is as a heartbreaking entity for individuals who analyze it from the linearity of viewpoints. Inevitably, the perceptions that emerged from experts, especially sociologists, also described this probability of existence.

Social conflict potentially occurs in a multi-religious society, especially in a multicultural society, ${ }^{1}$ like Indonesia. One of the factors that cause this to happen is the occurrence of human error in understanding religious texts. Some religious texts are interpreted "haphazardly" without considering the aspects of history, psychology, social, culture, and situational condition of the surrounding circumstances. ${ }^{2}$ This hence potentially leads to an intolerance related to differences in race, culture, and religion.

This then makes all parts of the society, especially social scientists, to work extra hard to find and propose a solution. One solution that is currently being discussed is the planting of values of tolerance and multicultural education. ${ }^{3}$ The discourse and dialogue movement among religious believers has made significant progress. This was initiated from the awareness that all religious people basically pursuing peace, compassion, and love as well as live happily with the people they love. To maintain integrity and unity in society, mutual respect and the balanced implementation of rights and obligations among the members of the society are required to prevent the root of intolerance would be transformed into a conflict.

Religious tolerance is a feature of the diversity of the nation of Indonesia that must be maintained. Amid a pluralistic society, the main capital of creating harmony is pursuing tolerance. By maintaining such an attitude, the act of intolerance can be reduced or even disappear. Some recent occurrences are caused by intolerance behaviors that resulted from a lack of education especially with regards to the core values of tolerance such as democracy, humanism, and pluralism.

Indonesia is a compound having a variety of ethnic, racial, cultural, linguistic, and religious diversity. In terms of religion, Indonesia recognizes several religions, namely Islam, Roman-Catholicism, Protestantism, Hinduism, Buddhism, and Confucianism. These religions have different principles and beliefs. The lack of social order to manage properly these differences would potentially cause conflicts. It is a general understanding

${ }^{1}$ See Ferdi Ferdian, Afrizal, and Elfitra, "Fungsi Forum Kerukunan Umat Beragama (FKUB) dalam Sistem Sosial Penciptaan Kerukunan Umat Beragama di Kabupaten Pasaman Barat," Islam Realitas: Journal of Islamic \& Social Studies 4, No. 2 (2018): 144

${ }^{2}$ The same thing that was conveyed by Burhanuddin Daya and Amin Abdullah that in understanding religion needed a multi-approach, namely integration-interconnection, so that religion did not seem "stiff" and even scary or frightening. Public Lecture on Interfaith and Cultural Dialogue on UIN Sunan Kalijaga Yogyakarta, 2010.

${ }^{3}$ Burhanuddin Daya, Agama Dialogis Merenda Dialektika Idealita dan Realita Hubungan Antar Agama (Yogyakarta: LKiS, 2004, Vol. I), 73. 
that conflicts between religions contradict the principles of religions which basically teach the values of peace. ${ }^{4}$

In mainstreaming religious tolerance, social tools need to be complemented by proper laws and regulations. For this article, there have been cited Law No. 7 of 2012 concerning Handling of Social Conflicts and its implementing regulation and Joint Regulation of Minister of Religious Affairs and Minister of Domestic Affairs No. 8 and 9 of 2006 concerning Guidelines for Task Implementation to Heads/Vice Heads of Regions in the Maintenance of Religious Harmony, Empowerment of Religious Harmony Forum, and Establishment of Place of Worship.

To realize these laws and regulations, the government and religious leaders have tried to uphold religious tolerance to create an intimate and harmonious relationship between religious people. In fact, there are still frequent conflicts and disputes that use "religious labels", such as mutual suspicion between Muslims and Christians and other religions, which are sufficient to prove the failure of advocates of "peace".

Based on the aforementioned background, this article argues the need for handling social conflict through the planting of tolerance values in multicultural societies that in line with statutory provisions. It is a socioreligious study, that to some extent applies a legal approach. A library study was conducted to gather the information that is relevant to the topic, that was collected from textbooks, scientific journals, and website contents. Besides, norms and principles as stipulated in laws and regulations were also cited to indicate the legal basis that has relevance to the topic discussed. The analysis is based on secondary data collection based on literature collected from various supporting literature. It applies Miles and Huberman's interactive analysis model which includes data reduction, data presentation, and conclusion.

\section{Result and Discussion}

\subsection{Reflecting the Theory of Social Conflict Resolution}

Conflict theory is a theory that considers that social change does not occur through a process of adjusting values that bring change, but occurs due to conflicts that result in compromises that are different from the original conditions. ${ }^{5}$ This theory is based on the ownership of production facilities as the main element of class separation in society. ${ }^{6}$ Conflict theory is the antithesis of functional structural theory, where functional structural theory places great emphasis on order in society. Conflict theory sees conflict and conflict in the social system. Conflict theory sees that in society it will not always be in order. The proof in any society must have experienced conflicts or tensions. Then the conflict theory also sees the existence of domination, coercion, and power in society. Conflict theory also talks about different authorities. These different authorities produce

${ }^{4}$ Inayatul Ulya and Ahmad Afnan Anshori, "Pendidikan Islam Multikultural Sebagai Resolusi Konflik Agama di Indonesia," Fikrah: Jurnal Imu Aqidah dan Studi Keagamaan 4, No.1 (2016): 23.

5 Bernard Raho, Teori Sosiologi Modern. (Jakarta: Prestasi Pustaka Publisher, 2007), 54.

${ }^{6}$ Verawati Muljana, Bab II Kajian Pustaka. Universitas Sumatera Utara, 2018. 
superordination and subordination. The difference between superordination and subordination can lead to conflict because of differences in interests. ${ }^{7}$

The theory of conflict suggests that conflict is necessary to create social change. When structural and functionalism suggest that social change in society always occurs at the equilibrium point, theory of conflict sees social change due to conflicts of interest. But at a certain point, the community can reach a mutual agreement. In conflicts, there are always negotiations that are carried out so that a consensus is created. 8 The theory of conflict is closely related to domination, coercion, and poweras it observes society that is united by "coercion," a regularity that occurs in society.

This theory aims to analyze the origin of an occurrence of a violation of rules or the background of someone who behaves deviant. The conflict here emphasizes the pluralistic nature of society and the imbalance in the distribution of power that occurs between various groups, because of the power possessed by elite groups, the groups also have the power to create regulations, especially laws that can serve their interests. ${ }^{9}$

The conflict is motivated by differences in the characteristics that individuals carry in an interaction. These differences include physical characteristics, intelligence, knowledge, customs, beliefs and so forth. With the existence of individual characteristics in social interaction, conflict is a natural situation that occurs in every community and no community has never experienced conflict between its members or with other community groups, this conflict will only disappear along with the disappearance of a community itself. 10

The description of the polemic on the basic point of view of conflict is illustrated through the Turner;s perspective:

"Conflict is thus designed to resolve dualism: it is a way to achieving some kind of unity, even if it be through the annihilation of one of the conflicting parties. This is roughly parallel to the fact that it is the most violent symptom of a disease which represents the effort of the organism to free itself of disturbances and damages caused by them."11

In line with Turner's statement above, Wes Sharrock in Pip Jones explained that the view of conflict is built on the assumption that every society can provide an extraordinary good life for some people but this is usually only possible because most oppressed people are suppressed. ${ }^{12}$

7 Ibid. See also M. Wahid Nur Tualeka, "Teori Konflik Sosiologi Klasik dan Modern," Jurnal Al-Hikmah 3, No. 1 (2017): 36

8 Verawati Muljana, loc.cit.

${ }_{9}$ Anonym, Teori Konflik Sosial Dalam Perspektif Karl Marx, Universitas Islam Negeri Sunan Ampel Surabaya.

10 Ibid.

11 Jonathan H. Turner. The Structure of Sociological Theory (Illiois: The Dorsey Pers, 1975), 84

12 Pip Jones. Pengantar Teori-Teori Sosial dari Teori Fungsionalisme hingga PostModernisme (Introducing social theory), translated by Achmad Fedyani Saifuddin (Jakarta: Yayasan Obor Indonesia, 2009), 15 and Sri Yuliana Agusalim, "Teori - Teori Sosial Pip, Jones (2009)." Slide Presentation. 
Therefore, differences in interests within the community are as important as agreement on rules and values, and most people are organized so that the community does not only provide greater benefits to some citizens, it means inconvenience for some other citizens who do not get convenience.

Based on Turner's analysis that since the 1950s, when Talcott Parsons's ideas collapsed, the tradition of criticism began to take a significant role in the building of social studies. ${ }^{13}$ Functional theory in the study of sociology as a variant of thought built by Parsons is considered as one of the causes of the emergence of the natural reality of conflict in social reality. This fact is also expressed by David Lockwood as explained by Turner that the perspective built by Parsons to create social equilibrium, on the other hand has created conceptual enmity in the social world.

The social equilibrium perspective built by Parsons, rests on several theoretical basic principles. The rationale Parsons developed according to the Giddens and Turner ${ }^{14}$ at the metatheory level was the integration between ideographic, ideal-type, nomological and constructivist methodologies. In concluding the analysis of Parsons's thinking, Giddens and Turner explained that each of the procedural forms can be analyzed with positivistic and idealistic variants. The steps that need to be realized as a continuation of this condition are to place a link between causal and teleonomic explanatory positivistic methods, with idealistic methods that highlight the normative and world aspects of life or rational interpretations.

The ideal of the theoretical integration model built by Parsons above, at different levels, was rejected by Marx's existence. Marx argues that changes in society are based on the presence of revolutions in their lives. This fact is in line with the statement of Nisbet in Ekeh ${ }^{15}$ that in the 19th century there was a quite pressing reaction to the individualistic reality that occurred in Europe. European sociologists think fundamentally that the subject of knowledge that can be responded to by the problem of order interests begins with the collapse of the old regime and the revolutionary spirit in democracy. The radical change that emerged was the emergence of the industrial revolution movement in France.

In developing a model of resolution between class conflicts and social change, Turner ignores Marx ${ }^{16}$ in a sketch that social organization will be influenced by the dominant portion of contemporary social theory. Marx began his study of simple things and general reality assumptions; economic organization, specifically on capital ownership, organizational determination in the interests of the organization. Class structure and organizational building, like cultural values, beliefs, religious dogmas, and other systematic ideas, as a whole from the existing reality occupies the highest level of economic reflection relying on social reality.

13 Jonathan H. Turner, op.cit., 78.

14 Anthony Giddens and Jonathan Turner, Panduan Sistematis Tradisi dan Tren Terdepan Teori Sosial (Social Theory Today), translated by Yudi Santoso (Yogyakarta: Pustaka Pelajar, 2015), 198.

15 Peter P Ekeh. Social Exchange Theory; The Two Traditions (London: Heinemann Educational Books, 1974), 3

16 Jonathan H. Turner, op.cit, 79. 
Conflict resolution at its basic level relies on the contradictory manifestations that arise from social areas. 17 Regarding this conceptualization, the contradiction in Martono's view is a central fact regarding everything that exists. These contradictions gave birth to a dialectical law. The law of the discipline asserts that contradiction is the essence of everything, both in nature and in human life. Community development takes place under dialectical law which consists of three components of thesis, antithesis, and synthesis.

The 1945 Constitution of the Republic of Indonesia determines that "Every person shall have the right to protection of his/herself, family, honour, dignity, and property, and shall have the right to feel secure against and receive protection from the threat of fear to do or not do something that is a human right" 18

The consitition also stipulates that "Every person shall have the duty to respect the human rights of others in the orderly life of the community, nation and state." 19 In exercising the rights and freedoms, every person obye the legal restrictions to ensure the recognition and respect of the rights and freedoms of others and of satisfying just demands based upon considerations of morality, religious values, security and public order in a democratic society. ${ }^{20}$ Regarding the religious activities, The State guarantees the freedom of worship according to individual religion or belief. ${ }^{21}$

Status of Conflict in a state of civil order up to civil emergency referres to in Government Regulation in Lieu of Law No. 23 of 1959 concerning a State of Emergency, ${ }^{22}$ in which the President may all or part of the territory of the Republic of Indonesia in danger with the degree of condition civil emergency or military emergency or state of war by reasons of, among others, security or law order is threatened. ${ }^{23}$ It, among others, reflects the application of a notion that the law acts as an important tool to create a safe and peaceful society. ${ }^{24}$

\subsection{Characteristics of Multicultural Communities in Indonesia}

Indonesia is a pluralistic country, both from the social, cultural, ethnic, racial, sectarian, and religious aspects. Therefore, Indonesian society is referred to as a multicultural society. Facing this condition, the Indonesian nation is required to be able to reconstruct a national culture that can be an

17 Nanang Martono. Sosiologi Perubahan Sosial: Perspektif Klasik, Modern, Posmodern, dan Poskolonial. (Jakarta: PT. RajaGrafindo Persada, 2012), 44.

18 Article 28G (1) of the 1945 Constitution of the Republic of Indonesia

19 Ibid., Article 28J (1)

20 Ibid., Article 28J (2)

21 Ibid., Article 29 (2)

22 Andi M. Faisal Bakti. Islam and Nation State Formation in Indonesia: From Communitarian to Organizational Communications (Jakarta: Logos Wacana Ilmu, 2000), 72.

23 Article 1 (1)(1) of Government Regulation in Lieu of Law No. 23 of 1959 concerning a State of Emergency

24 Muhammad Rinaldy Bima, "Implementation of State of Emergency Within The Constitutional Law System in Indonesia," Diponegoro Law Review 4, No.1 (2019): 123. 
integrating force on the diversity and heterogeneity of socio-culture, especially in religious life. ${ }^{25}$

In a multicultural society, it is emphasized that the diverse patterns of Indonesian society are intended not only for the diversity of ethnic groupsbut also for the diversity of cultures that exist in society. The existence of this cultural diversity can be seen in mutual respect, respect, tolerance between cultures. ${ }^{26}$ In this context it is emphasized, that differences are not a barrier to unite in realizing ideals in the life of nation and state as embodied in the 1945 Constitution of the Republic of Indonesia and Pancasila. ${ }^{27}$

The multicultural society is a society that has differences in ethnic groups, languages, religions, and customs. According to Ekstrand, a multicultural society is a society consisting of two or more elements living alone without any intermingling in one political entity. ${ }^{28} \mathrm{~A}$ multicultural society is a society consisting of two or more social groups, communities, or groups that are culturally, economically and politically separated (isolated), and have an institutional structure and are different from one another. ${ }^{29}$

The main reference for the realization of a multicultural Indonesian society is multiculturalism, which is a view that recognizes and admires diversity in unity, both individually and culturally. Multiculturalism can develop when supported by tolerance and willingness to respect each other.

Efforts to build a multicultural Indonesia can only be realized if: First, the concept of multiculturalism is understood to be the urgency of the Indonesian people and makes it a life guide. Second, there is a common understanding of the meaning of multiculturalism for the life of the nation. Third, the study of multiculturalism covers a variety of problems, namely politics and democracy, justice and law enforcement, employment and business opportunities, cultural rights of ethical and moral principles. ${ }^{30}$

Multiculturalism is not only discourse but is an ideology that must be fought for. It is really needed as a foundation for the establishment of democracy and the welfare of a plural society. Multiculturalism is not a stand-alone ideology but requires another concept that is used as a reference for understanding social life.

Van Den Berghe classifies six characteristics possessed by multicultural society, as follows: ${ }^{31}$

25 Eka Prasetiawati, "Urgensi Pendidikan Multikultural Untuk Menumbuhkan Nilai Toleransi Agama Di Indonesia," Jurnal Tapis 1, No.2 (2017): 297.

26 Ahmad Suradi, "The Development of Oriented on Multicultural Islamic Religious Education in School," Journal of Education and Learning 12, No. 3 (2018)

Read also Ahmad Suradi and Nurfitria Dewi, "Existence of Sufism in the Midst of Multicultural and Global Communities (Prospects and Problems of the Development), Jurnal Ushuluddin 27, No. 1 (2019): 107-120.

27 Eka Prasetiawati, op.cit., 289

28 L. H Ekstrand, "Multicultural Education" in International Encyclopedia of the Sociology of Education, ed. Lawrence J. Saha, (New york: Pergamon, 1997), 345-346.

29 Ahmad Suradi. Pendidikan Islam Multikultural (Yogyakarta: Samudra Biru, 2018), 302 and Ahmad Suradi, "The Challenges of Education Based on Multicultural in National Local Culture Conservation in Globalization Era," Jurnal Cendekia 16, No.1 (2018): 83.

30 Eka Prasetiawati, op.cit., 288.

31 Michael Banton. Racial and Ethnic Competition (New York: Cambridge University Press, 1983): 82-84. 
1. The occurrence of segmentation into forms of social groups. Diversity in the community can make people form certain groups based on the same identity so as to produce a different sub-culture with one another. For example, there are Malay, Batak, Palembang, and Serawai tribes live on Sumatera island that reprresent different culture and tradition.

2. Having the division of social structures into non-complementary institutions. Diverse communities make the structure of society experience differences between one community and another. The difference in the structure of society can be seen through social institutions that are not complimentary. For example, in a religious institution in Indonesia that houses several religions has a different structure. These religious institutions do not complement each other because the characteristics of the diversity of society (religion) are different.

3. Third, the lack of developing consensus (collective agreement). Diverse communities have different standards of values and norms that are realized through community behavior. This is because the characteristics of different communities are then adjusted to the physical and social conditions. Because of the diverse conditions of the community, collective agreements tend to be difficult to develop.

4. Conflicts occur relatively frequently. Differences that exist in society are one of the triggers for conflict. Conflicts that occur can be very diverse, ranging from conflicts between individuals to conflicts between groups. This can be caused by the lack of tolerance of one another, both between individuals and between groups.

5. Relatively, social integration grows because of coercion and interdependence in the economic field. If a multicultural society can be well-coordinated, social integration is very likely. However, social integration in society arises not because of consciousness, but from coercion outside the self or the group. Besides, the community has a dependency on the economic field which can encourage integration due to their needs. An example is an individual who works for another individual or company to make himself obey all the rules made.

6. There is political dominance. Certain groups in a multicultural society can have political forces that govern other groups. This becomes a form of domination (domination) from a group to other groups that do not have political power.

Azyumardi Azra introduced several types of multicultural society, as follows: 32

1. Asocyanist multiculturalism, which refers to a society where various cultural groups live autonomously and carry out minimal interactions with each other. For example, people in the "millet" system, they accept diversity but they maintain their culture separately from other communities.

32 Rizal Mubit, "Peran Agama Dalam Multikulturalisme Masyarakat Indonesia," Jurnal Episteme 16, No. 1 (2016):172-173. 
2. Accommodating multiculturalism, namely a pluralistic society that has a dominant culture, which makes adjustments, accommodates certain needs for minority cultures. Accommodative multicultural society formulates and applies culturally sensitive laws, laws and forces, allow minorities to develop their culture and minorities do not oppose dominant cultures. Multiculturalism can be found in England, France and several other European countries.

3. Automatic multiculturalism, a pluralistic society where the main cultural groups try to realize equality and want an autonomous life in a political framework collectively and acceptable. An example of this multiculturalism is Muslim communities in Europe who want their children to get equal education and their children's education following their culture.

4. Interactive critical multiculturalism, a pluralistic society in which cultural groups are not too concerned in the life of autonomous culture; but more demanding the creation of a collective culture that reflects and confirms their distinctive perspective. This multicultural, applies in the United States and the British black struggle (apartheid) in demanding independence.

5. Cosmopolitan multiculturalism, which seeks to eliminate culture eliminate to create a society where individuals are no longer bound and committed to a particular culture. He was freely involved with intercultural experiments and at the same time developing their respective cultures. The supporters of multiculturalism are diasporic intellectuals and liberal groups who tend to postmodernism and view culture as resources they can choose and take freely.

Socio-cultural diversity is the meaning of a multicultural society, indicates that there are various kinds of cultures that have their characteristics, which are different and can be distinguished from one and each other. Multiculturalism, simply can be formulated as a value system or policy that respects diversity in a society based on the willingness to accept and appreciate the existence of other groups of different ethnic, ethnic, gender and Islamic faiths since the beginning have taught values of respect and appreciation the differences that exist, whatever differences arise on this earth. ${ }^{33}$

Thus, various concepts relevant to multiculturalism include democracy, justice and law, cultural values and ethos, togetherness in equal differences, ethnicity, ethnic culture, religious beliefs, and community cultural rights. The problem faced with regard to efforts towards a multicultural Indonesian society is very complex.

\subsection{Planting Tolerance as Conflict Resolution}

The occurrence of social conflict in the name of religion (religious based-social conflict) is not a religious doctrine, because every religion teaches its people an attitude of tolerance and respect for others. Religious people are generally expected to be able to build a tradition of religious

${ }^{33}$ A. Suradi Jurnal Cendekia, loc.cit. 
discourse that respects the existence of other religions, and can present religious discourse that is tolerant and transformative. ${ }^{34}$

The success in realizing the noble goal of eternal peace and brotherhood among the people who in reality do have different religions and faiths can be gained the courage to invite knowing or understanding religious diversity. to describe mutual respect and cooperation among different groups of people, ethnically, linguistically, culturally, politically, or religiously. Therefore, the planting of tolerance values is a grand and noble concept that is fully an organic part of the teachings of religions, including Islam. Tolerance between religious people is important in daily life in society. Tolerance functions as a guardian, safeguard, peace-maker, and unifier in communication and interaction so that the preservation of the environment is maintained and the realization of good relations between members of the community. ${ }^{35}$

Tolerance is applied in the context of realizing a dynamic society, namely the awareness of peaceful and harmonious coexistence among a diverse Indonesian society. It can even be said that the continuity of unity in diversity and the growing awareness of the importance of acceptance of differences in society. For example, the community adheres to a number of different religions and beliefs, indeed there is no intolerance between communities that are of different faiths, not mutually hostile or there are conflicts that result in damage or loss of life, and there is no discrimination against minorities. However, the majority tolerate and interact well with the minorities, guarding each other's feelings and intentions, living side by side in peace. ${ }^{36}$

Tolerance is a modern concept to describe mutual respect and cooperation among different groups of people, ethnically, linguistically, culturally, politically, or religiously. Tolerance, therefore, is a grand and noble concept that fully becomes an organic part of the teachings of religions, including Islam. Religion that has entered the multicultural society will experience an acculturation process so that religion can have many versions especially in the aspect of implementation. 37

Tolerance values in a multicultural society are reflected from mutual respect between the majority and minorities. For example, Muslims and non-Muslims maintain harmony and peace where their places of worship are situated closely one and each other. A real example of tolerance values was discovered in Lalan Sub-regency, Musibanyuasin Regency, South Sumatera while celebrating the Month of Shuro in which Muslims conduct religious activities and donate almsgiving to not only Muslim fellows but also Christians and Hindus neigbours. Conversely, Christians and Hindu fellows regularly send foods to their Muslim neighbours when they celebrate their big religious festivals. Besides, during the holy month of Ramadhan, non-

\footnotetext{
${ }^{34}$ Nurcholish Madjid, Pluralitas Agama: Kerukunan dalam Keagamaaan; (Jakarta: Kompas Nusantara, 2001), 38-39.

35 S. Rizal Panggabean, Pola-pola Konflik Keagamaan di Indonesia (1990-2008), (Jakarta: Asia Foundation, 2009), 57

${ }^{36}$ Ali Maksum, Pluralisme dan Multikulturalisme Paradigma Baru Pendidikan Islam di Indonesia. (Jakarta: Aditya Media Publising, 2011), 135

37 Rizal Mubit, op.cit., 174.
} 
Muslims often attend berbuka puasa bersama (breaking the fast together) organised by Muslims, and help and distribute takjil to the poor peoples who lived surrounding them. ${ }^{38}$

From religion, what must be understood in analyzing conflict resolution and religious anarchism is that religion does not teach violence to the people. Religion preaches the existence of peace and love both for fellow believers and other people who have different beliefs. The existence of a conflict about religious anarchism itself is questioned by religion because it has become a distortion in the teachings of the religion. Religion is only an artificial identity in conflict to provide moral legitimacy to do violence against other parties. In addition to moral and identity legitimacy, igniting violence in the name of religion is also caused by errors in the interpretation of religious teachings which give rise to narrow understanding and chauvinistic attitudes. So in this context, there is no conflict between religious anarchism, which is precisely a conflict in the form of economic and political source rivalries and competition for public office in the government. 39

To build tolerant and cultured relationships in a multicultural society, at least two things are needed. First, reformulation of culture and reinterpretation of orthodox religious doctrines are used as excuses to be exclusive and comprehensive. Reformulation and reinterpretation must be done in such a way that culture and religion are not only receptive to the wisdom of local traditions but also guide in the vanguard to deliver built-in democracy in multicultural societies. ${ }^{40}$

Second, dialogue between tradition and religion with modern ideas. Today, the community enters a new historical phase where they must be able to adapt to large civilizations that are not based on tradition and religion, such as modern Western culture. We cannot avoid secular ideas and theories, and this touches on terms with non-religious ideas that are the most challenging tasks facing Muslims in modern times. ${ }^{41}$

Third, religion focuses on the teachings of love encourages people to respect, love, and help one and each other through their respective institutions which are usually expressed in social and religious activities. Fourth, religion indirectly encourages the creation of peace on earth which consists of pluralistic societies through these teachings. ${ }^{42}$

The concept of tolerance towards multicultural society is classified as accommodative multiculturalism, as Parekh argued by Azra, namely a pluralistic society that has a dominant culture, which accommodates certain needs for minority cultures. Accommodative multicultural society formulates and applies culturally sensitive laws, laws and forces, allow minorities to develop their culture, and minorities do not oppose dominant cultures.

38 Interview with Rohman, Islamic Scholar of Bengkulu City, at NU Office-Bengkulu, 2018.

39 Wasisto Raharjo Jati, "Sikap Toleransi Sebagai Resolusi Konflik Keagamaan," Jurnal Walisongo 21, no. 2 (2013): 394

40 John Haba. "Revitalisasi Sikap Toleransi: Studi Resolusi Konflik di Kalimantan Barat, Maluku dan Poso," in Agama dan Sikap toleransi dalam Tantangan Global, ed. Irwan Abdullah (Yogyakarta: Pustaka Pelajar, 2008), 150.

41 Ibid.

42 Ibid., 151 
Multiculturalism can be found in England, France and several other European countries. ${ }^{43}$

However, at the same time the need to revive discursive and dialogical space between ethnicities and religious communities also emerged is multiculturalism as part of post-materialism which would become a patron of conception in cultivating tolerance to be revitalized in a climate of conflict that could erupt at any time. The vital role of tolerance is as media for conflict resolution. First, tolerance is a sign of the identity of a community. This identity shows that the community has a culture of peace which means that the community is civilized. It is generally assumed tha conflict is a symbol of barbarian culture. Therefore, tolerance reflects the community desires s to portray itself as a peaceful community.

Secondly, tolerance itself provides a cohesive aspect in the form of adhesive elements across cultures and religions, cross-citizens, and beliefs. In this context, tolerance can be interpreted as a dialogical space or arena to dissolve all kinds of identity political exclusivity inherent among various groups. The effort to bridge various cross-interests is an effort to build inclusiveness in reducing the potential for greater conflict.

Third, it is different from the application of positive law as a media for conflict resolution which has been carried out by our law enforcers who have the impression of being "forced". For example, a legal mechanism to address the violation of rules on religious harmony makes the conflict resolution seems artificial and temporary in nature despite having permanent legal force. The attitude of tolerance as part of conflict resolution is more towards inviting all parties to negotiate by utilizing emotional and cultural closeness.

Fourth, tolerance gives color to togetherness for a community and can function to encourage the establishment of togetherness, appreciation, as well as a mechanism together to dismiss various possibilities that can reduce, even undermine communal solidarity, which is believed to originate and grow on a shared consciousness, from a community integrated. Fifth, the attitude of tolerance will change the mindset and reciprocal relationships of individuals and groups, by putting above the culture they have. Then it can be said that tolerance is a form of synthesis of sociocultural and socio-religious elements whose purpose is to re-establish relations between fellow citizens who are reduced to struggling for political and economic interests. ${ }^{44}$

Social conflicts that have a major impact on humanitarian issues are potential for human rights violations. As a country rich in ethnicity, religion, and culture, Indonesia is known as a democratic country with a high level of tolerance. ${ }^{45}$ However, the rise of social conflict that occurs shows that the function of tolerance does not work and there is something wrong with the

${ }^{43}$ Azyumardi Azra, Merawat Kemajemukan, Merawat Indonesia, (Yogyakarta: Kanisius, 2007), 73

${ }^{44}$ Nurma Ali Ridwan,"Landasan Keilmuan Sikap toleransi." Ibda: Jurnal Studi Islam dan Budaya 5, no.1(2007): 31.

45 Abu Hanifah, "Toleransi dalam Masyarakat Plural Memperkuat Ketahanan Nasional". Artikel Puslitbang Kemensos. 2014. Diunduh dari www. depsos.go.id tanggal 14 Mei 2020. 
way to treat it as the strength. 46 One government effort to prevent social conflicts is by caring for the diversity of the Indonesian nation through the re-grounding of the 4 Pillars of the Indonesian Nation, namely: maintaining the integrity of the Unitary State of the Republic of Indonesia; live and practice the values contained in Pancasila; Running the life of the nation and state based on the 1945 Constitution, and Strengthening the sense of unity as a nation of Unity in Diversity (Bhinneka Tunggal Ika). ${ }^{47}$

Up to now, there still exists the Joint Regulation of Minister of Religious Affairs and Minister of Domestic Affairs No. 8 and 9 of 2006 concerning Guidelines for Task Implementation to Heads/Vice Heads of Regions in the Maintenance of Religious Harmony, Empowerment of Religious Harmony Forum, and Establishment of Place of Worship (hereinafter, Joint Minister Regulation). The implementation of this Joint Minister Regulation was questioned. Some assessed that it implies discrimination that has increased religious intolerance, 48 while some others argued that it needs to be upgraded into a higher and legally binding regulation, rather than the current legal form. ${ }^{49}$ Recently, the Minister of Religious Affairs expressed his unwillingness to revise the joint regulation, but still opens for doing some reviews. 50

The Law No. 7 of 2012 concerning Handling of Social Conflicts was enacted by a great awareness by law-makers that hostiles and/or clashes between groups of people can cause social conflicts that result in disruption of national stability and impeded national development. 51 This Law acknowledges that conflicts can arise from clashes between different religious believers and/or the same religious believers, tribes, and ethnicities. ${ }^{52}$ Besides, the law covers three scopes of conflict management, namely conflict prevention, cessation of conflicts; and post-conflict recovery. ${ }^{53}$ Also, this law stipulates an individual obligation of all peoples to develop an attitude of tolerance and mutual respect for the freedom to practice worship accordingly with its religion and beliefs. ${ }^{54}$

To further implement that Law, the government adopted Government Regulation No. 2 of 2015 concerning Regulations for Implementing Law No.

46 Amin Abdullah, Pendidikan Agama Era multicultural-Multireligius (Jakarta: Pusat Studi Agama dan Peradaban PSAP, 2005), 29

${ }^{47}$ Elly M. Setiadi dan Usman Kolip, Pengantar Sosiologi Pemahaman Fakta dan Gejala Permasalahan Sosial: Teori, Aplikasi, dan Pemecahannya (Jakarta: Kencana Prenada Media Group, 2015), 378

48 Binsar A. Hutabarat, "Evaluasi Terhadap Peraturan Bersama Menteri Tahun 2006 Tentang Pendirian Rumah Ibadah," Societas Dei Jurnal Agama dan Masyarakat 4, no. 1 (2017): 28-29.

49 Liputan6, "Peraturan Kerukunan Beragama Perlu Jadi UU," 16 September 2019. https://www.liputan6.com/news/read/296574/peraturan-kerukunan-beragama-perlujadi-uu

${ }^{50}$ Kumparan News, "Menteri Agama: Belum Ada Niat Merevisi SKB 2 Menteri soal Pendirian Rumah Ibadah" 18 February 2020, https://kumparan.com/kumparannews/menteri-agama-belum-ada-niat-merevisi-skb-2menteri-soal-pendirian-rumah-ibadah-1srgtzEKLpz/full

${ }^{51}$ Law No. 7 of 2012 concerning Handling of Social Conflicts, Considerations, Part b

52 Ibid., Article 5 (b)

53 Ibid., Article 4

54 Ibid., Article 7 
7 of 2012 concerning Handling of Social Conflicts. The regulation was created to ensure the handling of social conflicts is carried out comprehensively, coordinated, and integrated in order to protect and provide a more optimal sense of community security. ${ }^{55}$ The Government and regional government carry out conflict prevention through, among others, activities to strengthen religious harmony; improvement of community harmony forums; and religious education and the planting of values of integration nationality; 56 In implementing conflict prevention, the Government and local government optimizing the peaceful settlement of disputes through deliberations to reach consensus in a respect to religious norms, moral norms, customary norms, and statutory provisions and by involving religious leaders, traditional leaders, and/or other elements of the community. .57

That government regulation also covers the issue of law enforcement, in which those who violate the law related to social conflict will be prosecuted in accordance with statutory provisions. ${ }^{58}$ Moreover, it enables the use of military force to assist the handling of social conflict after the government or regional government determines the status of a conflict situation, ${ }^{59}$ that in its implementation is coordinated by the police. ${ }^{60}$

\section{Conclusion}

The occurrence of social conflict is often motivated by differences in the characteristics that individuals carry in society. The success in realizing the noble goal of eternal peace and brotherhood and the prevention of social conflict among people who in reality do have different religions and cultures, and mutual respect and cooperation among different groups of people, ethnically, linguistically, culturally, politics, or religion. Therefore, planting tolerance values is a grand and noble concept that fully becomes an organic part of the foundation of our country. Tolerance functions as a guardian, safeguard, peace-maker, and unifier in communication and interaction so that good relations between community members are realized.

Besides the people who are realizing peace and brotherhood as an effort to prevent social conflict between different groups of people, the government is also actively protecting disunity and conflict between different communities. This is proven by the issuance of Government Regulation No. 2 of 2015 concerning Implementation Regulations of Law No. 7 of 2012 concerning Social Conflicts Resolution. This regulation aims to protect and provide an optimal sense of security for the community and the handling of social conflicts. It has covered the mechanism to address this matter by means of conflict prevention, cessation of conflicts, and post-conflict recovery.

55 Government Regulation No.2 of 2015 concerning Regulations for Implementing Law No. 7 of 2012 concerning Handling of Social Conflicts, Considerations

\footnotetext{
56 Ibid., Article 3

57 Ibid., Article 4 (3) and Article 7

58 Ibid, Article 9 (2)(g), Article 33, and Article 34

59 Ibid., Article 40 (1)

60 Ibid., Article 41
} 


\section{Book}

\section{BIBLIOGRAPHY}

Abdullah, Amin. Pendidikan Agama Era multicultural- Multireligius. Jakarta: Pusat Studi Agama dan Peradaban PSAP. 2005.

Azra, Azyumardi. Merawat Kemajemukan, Merawat Indonesia, Yogyakarta: Kanisius. 2007.

Bakti, Andi M. Faisal. Islam and Nation State Formation in Indonesia: From Communitarian to Organizational Communications. Jakarta: Logos Wacana Ilmu, 2000.

Banton, Michael. Racial and Ethnic Competition. New York: Cambridge University Press. 1983.

Daya, Burhanuddin. Agama Dialogis Merenda Dialektika Idealita dan Realita Hubungan Antar Agama. Yogyakarta : LKiS, 2004.

Ekeh, Peter P. Social Exchange Theory; The Two Traditions. London: Heinemann Educational Books. 1974.

Giddens. Anthony and Jonathan Turner. Panduan Sistematis Tradisi dan Tren Terdepan Teori Sosial (Social Theory Today), translated by Yudi Santoso. Yogyakarta: Pustaka Pelajar, 2015.

Jones, Pip. Pengantar Teori-Teori Sosial dari Teori Fungsionalisme hingga Post-Modernisme (Introducing social theory), translated by Achmad Fedyani Saifuddin. Jakarta: Yayasan Obor Indonesia, 2009.

Madjid, Nurcholish. Pluralitas Agama: Kerukunan dalam Keagamaaan; Jakarta: Kompas Nusantara. 2001.

Maksum, Ali. 2011. Pluralisme Dan Multikulturalisme Paradigma Baru Pendidikan Islam Di Indonesia. Aditya Media Publising.

Martono, Nanang. Sosiologi Perubahan Perubahan Sosial: Perspektif Klasik, Modern, Posmodern, dan Poskolonial. Jakarta: PT. RajaGrafindo Persada, 2012.

Panggabean, S. Rizal. Pola-pola Konflik Keagamaan di Indonesia (19902008). Jakarta: Asia Foundation. 2009.

Raho, Bernard. Teori Sosiologi Modern. Jakarta: Prestasi Pustaka Publisher. 2007.

Setiadi, Elly M. dan Usman Kolip, Pengantar Sosiologi Pemahaman Fakta dan Gejala Permasalahan Sosial: Teori, Aplikasi, dan Pemecahannya. Jakarta: Kencana Prenada Media Group, 2015

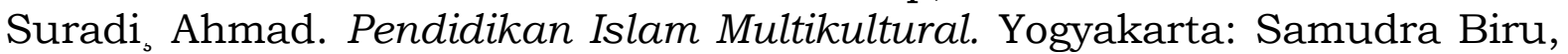
2018.

Turner, Jonathan H. The Structure of Sociological Theory. Illiois: The Dorsey Pers, 1975.

\section{Chapter in Book}

Ekstrand, L.H. "Multicultural Education" in International Encyclopedia of the Sociology of Education, edited by Lawrence J. Saha. New york: Pergamon, 1997.

Haba, John. "Revitalisasi Sikap Toleransi: Studi Resolusi Konflik di Kalimantan Barat, Maluku dan Poso," in Agama dan Sikap toleransi dalam Tantangan Global, edited by Irwan Abdullah. Yogyakarta: Pustaka Pelajar, 2008. 


\section{Journal Article}

Ulya, Inayatul and Ahmad Afnan Anshori. "Pendidikan Islam Multikultural Sebagai Resolusi Konflik Agama di Indonesia." Fikrah: Jurnal Ilmu Aqidah dan Studi Keagamaan 4, no.1 (2016): 20-35. https://doi.org/10.21043/fikrah.v4i1.1663

Bima, Muhammad Rinaldy. "Implementation of State of Emergency Within The Constitutional Law System in Indonesia." Diponegoro Law Review 4, no.1 (2019): $122-135$. https://doi.org/10.14710/dilrev.4.1.2019.122-135

Ferdian, Ferdi, Afrizal, and Elfitra. "Fungsi Forum Kerukunan Umat Beragama (FKUB) dalam Sistem Sosial Penciptaan Kerukunan Umat Beragama di Kabupaten Pasaman Barat." Islam Realitas: Journal of Islamic \& Social Studies 4, no. 2 (2018): 136-147.

Hutabarat, Binsar A, "Evaluasi Terhadap Peraturan Bersama Menteri Tahun 2006 Tentang Pendirian Rumah Ibadah," Societas Dei Jurnal Agama dan Masyarakat 4, no. 1 (2017): 8-31.

Jati, Wasisto Raharjo. Sikap Toleransi Sebagai Resolusi Konflik Keagamaan, Jurnal Walisongo 21, no.2 (2013).

Mubit, Rizal. "Peran Agama Dalam Multikulturalisme Masyarakat Indonesia," Jurnal Episteme 16, no. 1 (2016).

Prasetiawati, Eka. "Urgensi Pendidikan Multikultural Untuk Menumbuhkan Nilai Toleransi Agama Di Indonesia” Jurnal Tapis 1, no.2 (2017): 272 303. https://doi.org/10.32332/tapis.v1i02.876

Ridwan, Nurma Ali. "Landasan Keilmuan Sikap toleransi." Ibda: Jurnal Studi Islam dan Budaya 5, no.1(2007): 27-38

Suradi, Ahmad . "The Development of Oriented on Multicultural Islamic Religious Education in School," Journal of Education and Learning 12, no. 3 (2018): 493-500. http:/ / dx.doi.org/10.11591/edulearn.v12i3.8679

Suradi, Ahmad and Nurfitria Dewi. "Existence of Sufism in the Midst of Multicultural and Global Communities (Prospects and Problems of the Development). Jurnal Ushuluddin 27, no. 1 (2019): 107-120. http://dx.doi.org/10.24014/jush.v27i1.5355

Suradi, Ahmad. "The Challenges of Education Based on Multicultural in National Local Culture Conservation in Globalization Era" Jurnal $\begin{array}{llll}\text { Cendekia 16, no.1 103-124 } & \end{array}$ https: / / doi.org/10.21154/cendekia.v16i1.1156

Tualeka, M. Wahid Nur. “Teori Konflik Sosiologi Klasik dan Modern," Jurnal Al-Hikmah 3, no. 1 (2017): 32-48

\section{Law and Regulation of the Republic of Indonesia}

The 1945 Constitution of the Republic of Indonesia

Law No. 7 of 2012 concerning Handling of Social Conflicts

Government Regulation in Lieu of Law No. 23 of 1959 concerning a State of Emergency

Government Regulation No. 2 of 2015 concerning Regulations for Implementing Law No. 7 of 2012 concerning Handling of Social Conflicts. 
Joint Regulation of Minister of Religious Affairs and Minister of Domestic Affairs No. 8 and 9 of 2006 concerning Guidelines for Task Implementation to Heads/Vice Heads of Regions in the Maintenance of Religious Harmony, Empowerment of Religious Harmony Forum, and Establishment of Place of Worship

\section{Interview}

Interview with Rohman, Islamic Scholar of Bengkulu City, at NU OfficeBengkulu, 2018.

\section{Website Content}

Agusalim, Sri Yuliana. "Teori - Teori Sosial Pip, Jones (2009)." Presentation. http://slideplayer.info/slide/11836499/

Anonym, Teori Konflik Sosial Dalam Perspektif Karl Marx, Universitas Islam Negeri Sunan Ampel Surabaya. http://digilib.uinsby.ac.id/2560/5/Bab\%202.pdf

Hanifah, Abu. "Toleransi dalam Masyarakat Plural Memperkuat Ketahanan Nasional". Artikel Puslitbang Kemensos. 2014. Diunduh dari www. depsos.go.id tanggal 14 Mei 2020.

Muljana, Verawati, Bab II Kajian Pustaka. Universitas Sumatera Utara, 2018. $\quad \underline{\text { https://docplayer.info/71944337-Bab-ii-kajian-pustaka- }}$ mahasiswa-dapat-dikatakan-sebuah-komunitas-unik-yang-berada-dimasyarakat-dengan.html

Liputan6, "Peraturan Kerukunan Beragama Perlu Jadi UU," 16 September 2019. https://www.liputan6.com/news/read/296574/peraturankerukunan-beragama-perlu-jadi-uu

Kumparan News, "Menteri Agama: Belum Ada Niat Merevisi SKB 2 Menteri soal Pendirian Rumah Ibadah", 18 February 2020, https://kumparan.com/kumparannews/menteri-agama-belum-adaniat-merevisi-skb-2-menteri-soal-pendirian-rumah-ibadah$\underline{1 \text { srgtzEKLpz/full }}$ 